\title{
'The real problem is that when most economists wring their hands about the financial system melting down, what they really mean is the top 1 percent losing the amazing amount of wealth they've doubled since 1979'
}

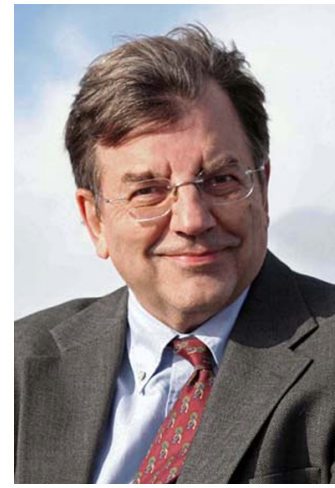

Interview with Michael Hudson

Michael Hudson is President of the Institute for the Study of Long-Term Economic Trends (ISLET), a Wall Street Financial Analyst, and Distinguished Research Professor of Economics at the University of Missouri, Kansas City. ISLET engages in research regarding domestic and international finance, national income and balance-sheet accounting with regard to real estate, and the economic history of the ancient Near East. Michael Hudson acts as an economic advisor to governments worldwide including Iceland, Latvia, and China on finance and tax law. He has published extensively on International Trade, Finance, and Debt, and co-edited volumes on the archeology of the ancient Near East.

\section{How did you become an economist?}

I came to New York from Chicago in 1960 in hope of becoming an orchestra conductor. I had a BA in German philology and history from the University of Chicago, but most of my training was in music, and I was going to study conducting with Dmitri Mitropoulos. A friend of mine from high school urged that I meet his girlfriend's father, Terence McCarthy, who was a leading mentor to many Wall Street analysts. In one evening Terence convinced me to become an economist. He told me about water levels rising and falling in the mid-West causing a crop cycle that in turn caused an autumnal drain of currency to move the crops, leading to financial crises when harvests were interrupted. It was as beautiful as astronomy or music to me, and I registered at NYU's graduate economics department to get my MA and then my PhD.

Terence was a former Irish socialist and the first translator of Marx's Theories of Surplus Value into English. (He used the French translation's title $A$ History of Economic Doctrines.) He became my mentor and said that I had to start by reading every book in the bibliography of Theories of Surplus Value. So, I began to study the history of economic thought. I was especially interested in Third World development and imperialism. Terence had proposed to replace or supplement the World Bank with an institution that would make domestic-currency loans to finance self-sufficiency in food. This would have involved breaking free of dependency on US farm exports to protect local agriculture. 
So I focused on trade theory, which was not even taught at NYU at that time. Meanwhile, I worked on Wall Street writing up statistics on how savings were recycled into real estate mortgages.

In December 1964, I went to work for the Chase Manhattan Bank as their balance-ofpayments analyst. Almost immediately, in January, President Johnson imposed his balance-of-payments controls to compensate for America's military spending in Southeast Asia. All of a sudden my job became very important. It was to trace the international flows of dollar payments, especially to get the oil industry exempt because it made so much money so quickly. It took me a year to write up its statistics. I later extended the analytic format I had developed to analyse the overall US balance of payments for Arthur Andersen. Then, after the US went off gold in 1971, I quickly wrote my book Super Imperialism (2nd edn, 2003). That made my career in 1972. I worked as a consultant for a Canadian brokerage house and became an advisor to the Canadian government. Ever since, my professional focus has been on international finance.

How did you become interested in probably the most important topic of your career as an economist: the cancellation of debt and the history of debt?

On the very first evening that I talked to Terence McCarthy he convinced me that there ultimately was going to be a financial crisis. He said that it probably was going to take around 50 years to erupt, and urged me to take a few decades to prepare for it. He had me read the works of Frederick Soddy, for instance, and the debate between Britain's bullionists and anti-bullionists in the early nineteenth century, and especially the Germany reparations debate in the 1920s regarding the 'theory of capital transfers.' By the late 1970s, I had become an advisor to the United Nations Institute for Training and Research (UNITAR). At a meeting in Mexico City on Third World debt, I repeated what I had been writing in UNITAR publications: that the debts could not be paid. There was a riot with shouting and walkouts. This made me realize that the topic was so important that I stopped doing current economic consulting and began to write a history of debt.

At the New School, where I had taught graduate economics from 1969-1972, the department chairman Robert Heilbroner said that my claim Third World debts could not be paid (later defended in my Super Imperialism) made my views unbelievable. It upset him that I was teaching Keynes's theory of capital transfers vis-à-vis Germany, and the rest of the works that I published in my lectures on Trade, Development and Foreign Debt (2nd edn, 2009). At the Institute of Policy Studies, Marcus Raskin and Richard Barnet also said that discussing debt writedowns for Third World or other debts would make them lose credibility. There was no anticipation of Mexico's 1982 default.

It amazed me that the political left has been less willing to look at debt problems than right-wing economists such as Austrians in the tradition of von Mises. Of course, they blame bubbles on government, not private banks, and advocate austerity rather than debt cancellation. But Marxists especially focus on labor-employer strains without seeing how the debt overhead is threatening industry as well as 'traumatizing' labor with the fear of missing a mortgage or credit-card payment. Heilbroner said that my focus on debt problems was distracting students from seeing capitalist exploitation at work.

\section{How did your particular interest in the issue of debt in Mesopotamia emerge?}

I saw that the only way to show the need for debt cancellations was to show how earlier societies had ended up having to cancel debts, and why they did this. It took me about 1 year to get back to Rome and Greece, as well as the Bible. But then I came across some sketchy hints about Babylonia. Back in 1980, if you looked in the index of books about 
Sumer and Babylonia there were no entries for debt. Yet cuneiform records are 99 percent about debt. But it was discussed continually in passing. So in order to find out about how it emerged, I had to read everything there was about Sumer and Babylonia. It was discussed in passing. Most important, I found that translations of debt cancellations were different in every language: German, French, English, and American. These royal proclamations were like Rorschach tests reflecting the preconceptions of the translator. Most books on the Jewish Jubilee Year said that it was only a literary topos, not really implemented. But the Babylonian antecedents obviously were implemented. In fact, Hammurabi's Clean Slates were enforced more than the letter of his more famous laws.

Clean Slates traditionally were proclaimed as a matter of custom. They included liberating bondservants pledged for debt, and redistributing land that creditors had taken. From Sumer, Babylonia, and their Bronze Age neighbors to the Bible's Jubilee Law, the features of antiquity's Clean Slate had the same details, and even the same word (andurarum in Babylonian, deror in Hebrew). I mentioned this to my friend Alex Marshack, who was on the Harvard archaeological faculty. He brought me up to the Peabody Museum in 1984, and its head, Carl Lamberg-Karlovsky, immediately put me on the faculty to write about Babylonian economic relations.

I spent the next 5 or 6 years writing about the origins of interest-bearing debt and its cancellations. Around 1992, I began to try and publish it. The University of California Press sent it to an assyriologist who replied that it was inconceivable to cancel the debts, because then nobody would have lent money, and every economy needed credit. He was a literary specialist, and didn't know that most debts were not loans but were arrears on unpaid bills to palace collectors by land renters or cultivators for water, draft animals, or simply for consumer goods such as beer - with payment to be made at harvest time, on the threshing floor. So the palace was annulling debts mainly owed to itself or its collectors (or perhaps to would-be wealthy rivals). Clean Slates kept the citizens free, so they could serve in the army, work on corvée labor projects, and maintain economic normalcy.

It was obvious that I was dealing with cognitive dissonance. So with Harvard's support, I organized a group of leading assyriologists and archaeologists in every period and region of antiquity to publish a series of colloquia on a separate topic of each of the main chapters of the book that I had drafted ('Bronze Age Finance: The Lost Tradition of Biblical Debt Cancellations').

Our group included the leading specialists of ancient Egypt, Mesopotamia, and Mycenaean Greece.

What struck me was that the mathematical training exercises taught to Babylonian scribes in $2000 \mathrm{BC}$ were superior to any of the mathematical models used today. They basically used two curves: the exponential doubling times of growth debt (every 5 years for commercial debt at 20 percent interest), and S-curves for the growth of herds or other economic activities. Today's economics students are forced to learn immensely complex mathematics that 'prove' that economies adjust to any debt burden. The interest rate was thought of as a doubling time. When you think of interest rates this way, you realize that financial claims can double while the economy doesn't. The Babylonians knew that harvests failed sometimes and debts could not be paid, and that imbalances built up over time, requiring balance to be imposed from 'above' the economic system.

Was there no more direct way of addressing today's problem of debt? Did you really have to go as far back as to the Mesopotamians in history?

I'm using ancient society as a foretaste of what's happening today. The conclusion is that Rome was the first society not to cancel debts - and creditor power brought on a Dark Age. So earlier experience provides a repertory of reasons why debt cancellations 
maintained economic stability. Mesopotamia also serves as a mind-expansion exercise to see how wide a range of policies economies have - and how very different economies all cancelled agrarian and personal debts when they grew top-heavy.

While I was doing this research in the 1980s, some of my friends worked for Drexel Burnham and the company that ultimately became the main sponsor of junk bonds. It was obvious already, when interest rates peaked in 1980, that a debt overload was coming. Default was avoided by the Federal Reserve flooding the economy with enough money to lower the interest rate and pay debts by borrowing against inflated asset prices. This was the beginning of the global debt binge, and I realized there was no point being called Doctor Doom at that point. I had been one of three people called Doctor Doom before 1980, along with Henry Kaufman and Al Wojnilower. I didn't want to be called a premature doomsayer. So, I spent most of my time preparing my historical research and working out my own economic model until 10 years ago, when it became apparent that there was going to be another debt crisis.

By that time, I began to write in popular journals. I had to go on record that all of this was foreseeable. I published three cover stories in Harper's. There is much more public willingness to talk about the impossibility of repaying debts than there is among mainstream economists. I forecast Mexico's 1982 debt collapse in my articles for UNITAR, and earlier had written about its inevitability in Super Imperialism and Global Fracture. But academic economics wasn't about this kind of analysis. They don't want realism but a happy fiction. What you get in academic economics is like a Hollywood version of It's A Wonderful Life; a wonderful story that all you need is enough credit and an economy borrowing its way out of debt. Even though it's silly when you try to do the mathematics, it's what the profession teaches.

People seem to be more willing to look at the dynamics of debt when it's about a society 4000 or 5000 years old. In dealing with today's debt problems, ideological blinders come into play. Cognitive dissonance is the biggest problem when talking about money and debt relations. People are unwilling to recognize that many debts are not payable on a large scale. Economic textbooks assume that debts can be paid, yet no economy in history has ever paid its debts. Based on that observation by Adam Smith (regarding public debts), I'm able to lead students or readers into a discussion of the modern world and how similar the dynamics have been throughout history.

In your most recent book, The Bubble and Beyond (2012), you explore the distinction between earned and unearned income. Why is this so statistically important?

The most important thrust of classical economics was to free industrial economies from the legacies of feudalism: hereditary rentier land ownership, and a predatory credit system that was not geared to financing industrial capital formation. Most 'wealth' took the form of rentier claims on income, not the means of production. The FIRE sector - finance, insurance, and real estate - is still in this category. But in the late nineteenth century, postclassical economists adopted a 'value-free' analysis that assumed that everyone earned whatever income and wealth they had - regardless of how they obtained this income. So today's National Income and Product Accounts (NIPA) assume that the more rent and interest are squeezed out of the economy, the more 'product' is created. Classical economists would view this rentier income as a subtrahend, not product. They wanted to tax land rent away, because it's created by private investment in infrastructure and by the general level of prosperity. Today's mainstream economists want to privatize it as a free lunch.

The NIPA should separate actual production and its economically necessary costs from FIRE sector overhead that simply extracts the surplus that's produced by the productive sectors. Interest, economic rent, and monopoly pricing are charges ('empty prices') that do 
not have a counterpart in the cost of production. Such income does not represent an actual service being produced.

I don't think any university teaches courses in the National Income and Product Accounts (NIPA) or even the Federal Reserve's Flow of Funds. Without learning the analytic categories of classical economics, students won't come to realize how radically post-classical economics has stripped away from our statistical picture of 'empirical reality' the concepts of economic rent and unearned income, unproductive credit and other areas that need to be reformed if we are going to get the economy back on a progressive track.

Let's talk about the debt issue and debt cancellation proposals. You are well known for the dictum: debts that can't be repaid - won't be repaid. The obvious and often-raised counter-argument is that if you cancel all debts, this will lead to a meltdown of the financial system.

This question was central to the American government policy after the 2008 meltdown. Sheila Bair, head of the Federal Deposit Insurance Corporation, wanted to close down CitiBank. In her narrative, Bull by the Horns, she said that Tim Geithner said that this would cause a meltdown. She replied that the FDIC is in the business of closing down banks, as she'd just done with crooked WaMu. There was plenty of money to pay all the insured depositors at CitiBank. What would go down was the overgrowth of derivatives, trades, and gambles. When they talk about the financial system collapsing, what they mean is casino capitalism's superstructure of derivatives. They don't mean industrial capitalism or bank funding to industry and individuals, because the money market funds have already led companies to bypass the banking system. They mean the whole set of gambles on the movements of interest rates and arbitrage, which Ms Bair and others have said aren't necessary for the industrial economy to function.

As matters turned out, Geithner simply refused to close down Citigroup. The Bush and Obama administrations chose to rescue the banks rather than the economy. Bad debts were left in place, not written down. That's still stifling recovery right now, in many countries. The financial system has become dysfunctional - and worse, it looks like it has been infected with crooks. My UMKC colleague Bill Black points out that many debts and claims are fraudulent and that banksters should probably be thrown in jail, as they were when he was a regulator in the 1980s.

What people call 'the financial system' has become like a tumor on retail banking people's checking accounts, savings accounts, or credit cards. There never was a danger of these being shut down. That was a scare tactic mounted by Wall Street speculators. They threatened to create disaster if the government didn't bail them out. A much better option would have been for the government to have taken over Citigroup, Bank of America, Wells Fargo, and other insolvent banks, left uninsured bondholders, stockholders, and counterparties to lose their gambles, and keep these banks operating as a public option, something like Post Office banks used to operate here and like they still do in Japan and Russia. This option could have provided inexpensive credit cards and cheaper basic services at lower interest rates than the bank monopoly now imposes. So instead of 'melting down,' writing off the derivative claims and counter-claims, junk mortgage debts, and outright fraudulent 'liars' loans' would have replaced a sick financial system with a healthier and more productive one.

The real problem is that when most economists wring their hands about the financial system melting down, what they really mean is the top 1 percent losing the amazing amount of wealth they've doubled since 1979. The US Congressional Research Office calculates that 95 percent of the gains in the economy have accrued to the top 1 percent since 2008. So when people talk about economic recovery and 'wealth creation,' they really 
mean the wealth of the upper 1 percent who hold the 99 percent in debt. There is an immense amount of liquidity in the world that are the savings of dictators, kleptocrats of the former Soviet Union, and drug dealers. If this set of financial claims on the economy is paid, the whole world economy is going to be forced into depression. Wiping out these claims - especially the bad loans that were bailed out - would return the distribution of wealth to what it was a generation ago at the outset of the neoliberal power grab. The alternative - our present path - is to force the whole world into depression and debt deflation, causing a meltdown of the real economy in order to save the 1 percent. The 'financial meltdown' you cite simply means that the 1 percent loses its money and we protect the 99 percent. Something has to give.

\section{What would be your advice for the Greek government?}

For starters, say it cannot pay the debts. Add that, legally, these were not undertaken democratically. It was obvious that most Greeks opposed last year's bailout. Recognizing that a majority would vote against it, Angela Merkel and others were against the referendum proposed by the Socialist Pasoc party on whether to push the country into a lost decade of austerity. The Greeks thus can claim that the debts were imposed by foreigners, equivalent to an act of war. That's what high finance is today, after all. National financial takeovers have the same aims as military conquest 1000 years ago. The land, public infrastructure, natural resources, mineral rights, and monopoly privileges are taken over by finance, not by armies.

The major private holders of Greek debt are now vulture investors and hedge funds that are said to have bought Greek debt for about 17 cents on the dollar. The Greeks could either pay this (Argentina-style), or just say that they are going to stand up for democracy and not pay - and ask Europe, 'What are you going to do about it?'

How would you do it, technically, and how would you prevent the Greek financial system from meltdown and spillover to euro area countries?

The starting point is to quantify Greece's ability to pay debts - without forfeiting the public domain or dismantling basic social spending. Then, insist on the basic principle that debts that can't be paid without destroying an economy should be written off, as German reparations and Inter-Ally debts were in 1931. The logic was spelled out by Keynes in the 1920s, which I describe in my trade theory book. Having been misled by the European Central Bank's junk economics, Greece should threaten to withdraw from the eurozone if the EU financial bureaucracy does not annul these unpayable debts. It should start seeking allies to take with it, starting with Cyprus, and talk to other debt-strapped eurozone countries in the same boat.

At the same time, Greece needs to address its own elite's tax dodging and fraud. The government has asked Swiss banks to trace capital flight. Greece's foreign debt is about $€ 45$ billion, and Swiss banks hold $€ 50$ billion of Greek flight capital. The government might propose that creditors collect them from the Swiss, which is where the money is.

The strategy should be to ask Europe, 'What are you going to do? Do you want us to join the Shanghai Cooperation Organization? There are many groups that we can join and we don't need to be part of Europe if that means collapse and depopulation. We can go and help Turkey re-establish the Ottoman Empire.' Among other things, Greece should stop its military spending and withdraw from NATO on grounds that it can't afford it. It should return the submarines and other weaponry it has bought from Europe, saying that the sellers failed to do due diligence on Greece's ability to pay. It might negotiate with 
Russia, China, and even its long-time enemy Turkey for alliances of various sorts. The basic issue is whether it is worth tearing Europe apart to let hedge funds make a killing on debt they've bought on credit for 17 cents on the dollar, having borrowed the money from the big banks and put down only about 5 percent of their own money. The ECB has simply printed the money. It can forgive Greek debt without destroying northern Europe's economies.

Do you think that the recent crisis will change academic economics? Is there a chance for change in the economics departments or do you think that change has to come from outside?

We're in a situation today very much like the US was in after the Civil War. At that time all the prestige colleges, such as Harvard and Princeton, taught British free-trade theory, as did universities in the South. Republican policymakers tried to develop a logic to defend protectionist policies and guide public infrastructure investment. But universities in New England were largely funded by traders, and the South opposed industry because it wanted low grain prices to feed the slaves. So the US Government created state landgrant colleges. It was easier to start afresh with pro-industry teachers than to change existing free traders. Industrialists funded business schools, starting with the Wharton School at the University of Pennsylvania. Economics today is in a similar pre-revolutionary situation. You cannot reform the departments that are led by neoliberal censors who impose a tunnel vision. You need a new department. Some non-neoliberals call themselves 'geographers,' as others called themselves 'sociologists' a century ago.

Was that another reason why you left academia and tried to influence the economic policy discourse from the outside?

I stopped teaching at the New School in 1972 because there was little room to fit finance, economic history, or the history of economic thought into the curriculum. So I worked for think tanks and kept up on financial developments by consulting for Wall Street firms, and in time also for foreign governments and opposition to neoliberal governments in Latvia, Iceland, and Russia. About a decade ago I began to write for Harper's, the Financial Times, and other media to make it harder for the academic profession to ignore the economic problems that the public recognized were important.

I found that one is only taken seriously in the academic economics profession if you're able to create a constituency among some political groups. That led me to become economic advisor to the progressive Congressman Dennis Kucinich. One of the things that he introduced was the Chicago Plan as a means of getting into public debate the need for a public option in banking, and to show how different sound lending for production would be from Wall Street's lending to inflate asset prices.

The greatest interest in debt has come not from an economist but from my friend David Graeber's anthropological book Debt: The First 5000 Years. This went together with his efforts to organize Occupy Wall Street. I must admit that I didn't think that people would accept a discussion of debt cancellations in antiquity until I wrote my modern theory to describe the coming need for Clean Slates. That's why I left my economic history work to be published by Harvard and other assyriology publishers, for assyriologists to make sure I had their agreement. But Graeber wrote up my historical approach from his anthropology perspective, and succeeded in becoming very popular. It turns out that people in general are more interested in debt than academic economists are!

So for me, the moral is to make an end-run around economics and go straight to the public and to political leaders and reformers. 
Considering the way you have tried to change economics and influence economic policy, do you think of this as a role model for other heterodox economists? Or do you think it would also be necessary to institutionalize a new kind of pluralism in economics and change university economics departments?

A quantum leap needs to take place. After America's Civil War, when the prestige colleges taught Ricardian free-trade theory, the government sponsored state universities to teach a more realistic, technology-based economics. Later, the American Economic Association was formed by economists who had studied in Germany and came back to develop a more social and historically based alternative to classical free-trade theory. Something similar is beginning to emerge today, especially outside of the US. I've been coming to conferences of the research network Macroeconomics and Macroeconomic Policies for 5 to 6 years, and these Berlin conferences are a natural complement to the curriculum that we've developed at UMKC. China has a wide variety of approaches. There is a growing group of stellar individuals who are able to come together for particular meetings. At some point in the future this will take an academic form and coalesce into a distinct new discipline, much like 'sociology' was created out of institutional economics a century ago.

I'm not sure what to call the needed 'reality economics.' Somebody needs to suggest a new label, in order to institutionalize the historical approach. That is what Germany did in the late nineteenth century with its Historical School, and also what the French did with their emphasis on engineering, in contrast to English utilitarianism and Austrian anti-government individualistic defense of the status quo without regard for how inequitable it was.

What makes the task of intellectual reform of economics harder today than it was in the nineteenth century is that you don't have a set of vested interests to support this kind of reality economics - except in Third World countries, and one would think in Russia and China. In the United States, as I mentioned above, wealthy businessmen wanted to show that every country needed protective tariffs to catch up with Britain's industrial dominance. And the US and Germany succeeded quite well. Today, what is needed is protection against global finance and its anti-government, anti-labor austerity doctrine. I'm surprised that there is not stronger support for this.

\section{What would be your career advice for young economists?}

The way that today's economic discipline is taught is not much help if they are interested in how economies really work and want to make the world better. They must go beyond their schoolwork to learn about economic history and classical economics, especially rent theory and the Banking-Currency School debate in Britain in the 1840s, and the German reparations debate. Today's discussion of money neglects the economy-wide impact of debt. I learned about it by going to work in the field, but banks no longer do much research as they did in my day. So students will need to spend a lot of time reading and teaching themselves.

It's almost impossible to get the kind of economic education today that I received 50 years ago. Neoliberals have taken over and censored reality out of the curriculum. Junk economics ('equilibrium' theory) postulates a 'what-if world' with little debt or inequality, or explanation of why wealth ownership is polarizing. When I went to NYU, bad as it was, it at least had required courses in the history of economic thought and economic history. These topics are now excluded from the curriculum, mainly to support Margaret Thatcher's neoliberal insistence that 'There Is No Alternative' (TINA). The way to make sure there is no alternative to today's austerity programs, debt deflation, and privatization rip-offs is to not expose students to ideas that there is indeed an alternative. 
After all, classical economists were reformers trying to free economies from economic rent-seeking and predatory credit. But today's 'free markets' are free for predators, not free from the rentiers. Today's Orwellian version of the economics vocabulary turns classical economics upside down. In the US the Chicago Boys have stripped out of the curriculum what's embarrassing to them, especially debt and the concept of unearned income as economic rent - the excess of market price over cost value.

Already, by 1972, many of my best students were deciding to leave the field because they were not interested in learning higher mathematics designed to prove that the present way of doing things is the best. They wanted to make the world better, not just to make money for corporations or Wall Street. If today's economics students seek reforms, they're excluded from the mainstream. That's been the fate of many UMKC graduates teaching Modern Monetary Theory (MMT) and criticizing Wall Street neoliberalism. The economics discipline is bifurcating between individualistic libertarians and economists who look at the broad picture. The best way to get a sense of perspective and good judgment is to study financial history and rent theory.

The interview was conducted by Achim Truger and Till van Treeck in Berlin in October 2012.

\section{SELECTED PUBLICATIONS BY MICHAEL HUDSON}

\section{Economics}

Hudson, M. (1972): Super Imperialism: The Economic Strategy of American Empire, New York: Holt, Rinehart, and Winston. (2nd edn, London: Pluto Press 2003.) (Translated into Japanese.)

Hudson, M. (1975): Economics and Technology in 19th Century American Thought: The Neglected American Economists, New York: Garland Press. (2nd edn published as America's Protectionist Takeoff: 1815-1914, New York: ISLET 2012.)

Hudson, M. (1977): Global Fracture: The New International Economic Order, New York: Harper and Row. (2nd edn, Pluto Press 2005.)

Hudson, M. (1992): Trade, Development and Foreign Debt: A History of Theories of Polarization $v$. Convergence in the World Economy, London: Pluto Press. (2nd edn, New York: ISLET 2009.)

Hudson, M. (2012): The Bubble and Beyond, New York: ISLET.

Hudson, M. (2012): Finance Capitalism and its Discontents, New York: ISLET.

Hudson, M. (2014): Killing the Host: Financial Parasitism and Wall Street's War on Capitalism, New York: Nation Books.

\section{Archeology of the Ancient Near East}

Hudson, M., Van de Mieroop, M. (eds) (2002): Debt and Economic Renewal in the Ancient Near East, Baltimore: CDL Press.

Hudson, M., Wunsch, C. (eds) (2004): Creating Economic Order: Record-Keeping, Standardization and the Development of Accounting in the Ancient Near East, Baltimore: CDL Press.

\section{REFERENCES}

Bair, Sheila (2012): Bull by the Horns: Fighting to Save Main Street from Wall Street and Wall Street from Itself, New York: Free Press.

Graeber, David (2011): Debt: The First 5,000 Years, New York: Melville House. 